This article was downloaded by: [University of Toronto Libraries]

On: 01 January 2015, At: 11:02

Publisher: Routledge

Informa Ltd Registered in England and Wales Registered Number: 1072954

Registered office: Mortimer House, 37-41 Mortimer Street, London W1T

3J H, UK

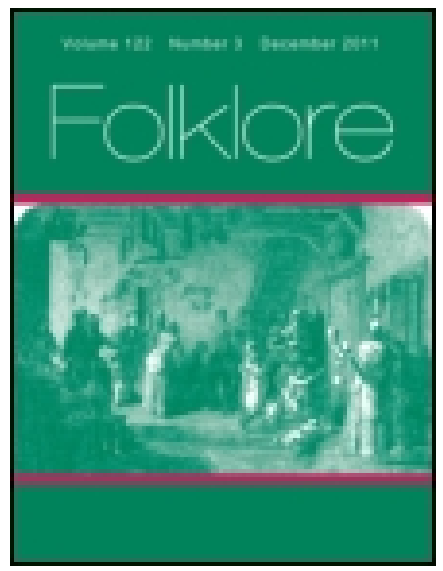

\title{
Folklore
}

Publication details, including instructions for authors and subscription information:

http:// www. tandfonline.com/loi/ rfol20

\section{A Folklore Survey of County Clare (Concluded)}

Thos. J. Westropp

Published online: 06 Feb 2012.

To cite this article: Thos. J. Westropp (1912) A Folklore Survey of County Clare (Concluded), Folklore, 23:2, 204-215, DOI: 10.1080/ 0015587X.1912.9719522

To link to this article: http:// dx. doi. org/ 10.1080/0015587X.1912.9719522

\section{PLEASE SCROLL DOWN FOR ARTICLE}

Taylor \& Francis makes every effort to ensure the accuracy of all the information (the "Content") contained in the publications on our platform. However, Taylor \& Francis, our agents, and our licensors make no representations or warranties whatsoever as to the accuracy, completeness, or suitability for any purpose of the Content. Any opinions and views expressed in this publication are the opinions and views of the authors, and are not the views of or endorsed by Taylor \& Francis. The accuracy of the Content should not be relied upon and should be independently verified with primary sources of information. Taylor and Francis shall not be liable for any losses, actions, claims, proceedings, demands, costs, expenses, damages, and other liabilities whatsoever or howsoever caused arising directly or indirectly in connection with, in relation to or arising out of the use of the Content.

This article may be used for research, teaching, and private study purposes. Any substantial or systematic reproduction, redistribution, reselling, loan, sub-licensing, systematic supply, or distribution in any form to anyone is 
expressly forbidden. Terms $\&$ Conditions of access and use can be found at http://www.tandfonline.com/page/terms-and-conditions 


\section{A Folklore Survey of County Clare (concluded).}

\section{Earthworks and Buildings.}

FAIRY forts and mounds have been dealt with in Section iv., haunted houses in Section viii., and foundation sacrifices in Section xi.

Forts.-The ring walls and mounds in County Clare are probably residential, or, more rarely, sepulchral, but certainly not military. They consist of one or more walls (or banks), usually slightly oval, and the earthworks have fosses and traces of stone facing. They are named $d u n$, lis, rath, and even caher (cathair), but the last name is usually reserved for the dry stone ring walls. Ooan (uamh) is used both for forts and for artificial caves in them, and also, for a fort-souterain, in 1317 in the Cathreim Thoirdhealbhaigh (History of the Wars of the O'Briens and de Clares). The country people have no limited views as to the makers of the 2400 forts in Clare. Croaghateeaun near Ballinalacken is attributed to the ancient deities, the Danánn, and one should cross oneself in entering its garth. ${ }^{1}$ Mohernagartan and Mohernaglasha were made by the smith god Lon,-the latter for the grey "cloud and rain cow," the Glas. Oisin the poet lived in Caherussheen near Corofin, and the great stone fort on Turlough Hill probably belonged to the "Irish Mfilitia" (Finn's warriors). Chonan, one of Finn's men, dwelt in the now levelled fort on Keentlae (ceannt tsleibh) on Inchiquin Hill.2 Three contemporaries, Crochaun (lumped hill), Dahlin, and Sall (the brine), made the forts bearing their names at Loop Head, and one at Cahernaheanmná near them for their sister the beloved of the hero Dermot O'Duine.s Oircheannaigh "of the golden cap" made the vast triple Moghane for his "fighting ring." A giant dwelt in the promontory fort of Doonaunmore at Ballinahown who lost his magic staff and was

1 The Jourmal of the Royal Society of Antiquaries of Ireland, vol. xxxv., p. 345 .

"Feis tighe chonain."

"The Journal of the Royal Society of Antiquaries of Ireland, vol. xxxviii., p. 351.

Ibid., vol. xxiii., p. 281; Proceedings of the Royal Irish Academy, vol. xxvii., pp. 218 et seq. 
slain. ${ }^{5}$ Another Fhir mór (or huge man) was hunted from Cahermurphy stone fort to Kiltumper, where he was slain and buried. ${ }^{6}$ Caherdooneerish was in the tenth century reputed to have been made by Irgus, a Firbolg, at the beginning of our era; it was wrongly attributed by scholars to Fergus, son of Roigh, but the peasantry never abandoned the name of the brother of Aenghụs of Dun Aengusa in Aran.

Unlike some old schools of antiquaries, the people did not overlook the later origin of some forts, for they attributed the Grianan and Bealboruma to King Brian Boru (c. 1000), the former to defend his horse-paddock (parc an each) on the shoulder of Craglea. The fort of Lisnagry, in the heart of the hills near Broadford, was reputed to be the hiding-place of the great king's cattle from the Danes. King Croohoore (Conor) na Siudaine O'Brien (slain 1267) was said to have built Dunconor, the great stone fort in Inishere Aran which MacLiag's poem (c. 1000) attributes to Conchraid the Firbolg. The same king, we may note, executed the latest earthworks of a fort recorded in Clare history, at Clonroad, completing the royal rath commenced by his father and left unfinished in 124I. Some rebuilding of Dun Conor may quite conceivably have been undertaken in his reign.

To the fairy forts previously mentioned should be added Lissateeaun, near Lisdoonvarna. The people of Tulla had an observance by which the instigator of the destruction of a fort assumed the blame and freed the workman.

Churches.-The church of Clonlea once stood at the opposite side of the lake, near St. Senan's well in Killaneena, whence one night it travelled down the old lane that runs into the lake, passed under the water, and reached its present site. King Conor na Siudaine built Corcomroe Abbey, and, as soon as his five skilled masons had completed the beautiful chancel and chapels, he put them to death lest they should build a rival masterpiece elsewhere; This legend is now being transferred through modern guide-books, the careless compilation of which is a great source of corruption of our legends, to Donald O'Brien, the actual, but not traditional,

The Journal of the Royal Society of Antiguaries of Ireland, vol. xxxv., p. 346 .

- Orạnance Survey Letiers (Co. Clare), vol. i., p. 205. 
founder of the building, and is held to explain the rude and inferior work of parts of it. Quin "Abbey" was built by the famous Master Mason Gobbán Saor, who twisted the spiral pillars of its beautiful cloister with his own hands. The builder of the south transept (1433) fell from its gable, and was killed where a tombstone with the scribed figure of an axe marks his grave. The north-west corner of Carran church overhangs, and is destined to fall on the wisest man that shall pass below it.

Castles.-A belief similar to that about Carran church was. attached to Ballymulcassel or Mountcashel castle. It is a peel tower, built by King Conor na Srona, about 1460 , on a steep littleknoll of rock beside the road from Sixmilebridge to Kilkishen. It was to fall on the handsomest person, and gossip told of a very ugly man who always took a longer road to avoid passing it. The same legend and gossip was attached to Newcastle peel tower, near Limerick and not far from the border of Clare. A wizard who lived in Shalee castle was so pestered by his wife that he flew away with half the tower, which remains as Glen castle near Ennistymon station. A guest praised Dysert castle to its owner, O'Dea, and wished that it were full of gold. "I'd rather have it full of O'Hiumhairs," replied O'Dea, ${ }^{7}$ the family so complimented being a small but warlike clan, of which one member fought in the wars of $13^{1} 3^{-8}$ and is reported to have slain Richard de Clare at Dysert in 1318 . I heard in 1869 that the castles near Doonass. were built by seven brothers, and that six came to an untimely end at the hands of the seventh, but the legend seems now forgotten at Clonlara.

Round Towers.-The peasants seem never to have adopted the various druidic, Cuthite, phallic, and other theories of 1750 onwards from the so-called "educated classes." To them, as to our earlier writers, the towers are steeples built by saints. John Lloyd, in $1780,{ }^{8}$ calls that of Scattery "the loftiest old Steeple in the Kingdom." Michael O'Brannan, in $\times 194,{ }^{9}$ tells how St.

Torduance Survey Letters (Co. Clare), vol. i., p. 157. The tale closelyresembles a legend of St. Caimin of Iniscaltra and Guaire Aidhne at Iniscaltra, Lough Derg.

A Short Tour etc., p. 21.

- Poem on Shannon, Ordnance Survey Letters (Co. Clare), vol. ii., pp. $15-8$. 
Senan "built seven churches and a beautiful high belfry" there, and how "St. Caimin, a vigorous chieftain, erected seven churches and a high belfry" on Lough Derg. Legend told that St. Senan, while building his tower, was interrupted by a woman, and left it unfinished. ${ }^{10}$ St. Blawfugh (Blathmac) built two towers at Rathblamac, one of which was stolen and brought to Dysert O'Dea by St. Manawla. Of the bells of Dromcliff and Kilnaboy towers I have already told." Kilnaboy tower was broken down by "the bombardment of Cromwell." The round tower at Tomgraney was faintly remembered, in Petrie's time, as like that on Iniscaltra, but it has long since been forgotten.

Crosses and monuments.-I have already mentioned the cross of Dysert O'Dea, ${ }^{12}$ which was unusual in having portions of its carvings on separate pieces of stone, some of which are lost. The cross fell twice, and was re-erected by Conor Crone O'Dea in 1683 and by Col. Synge of Mount Callan in 1872 ; each benefactor died in the year following his restoration of the cross. The breaking off or fall of any portion of the monument of Sir Donal O'Brien, the first of the baronets of Dromoland, in Kilnasoolagh cluurch, is fatal to his descendants, and so is any attempt to clean or repair it, tradition alleging that one of the O'Briens always dies in either case.13 My own family believed that, if the family vault were opened, it had soon to be opened twice again to receive new occupants.

Underground passages.-One is said to lead from Cahercrochaun to Dundahlin on Loop Head, and another from the great promontory fort of Dundoillroe eastwards, where a brown track, probably an old road, still remains. A third ran through Barnagoskaigh to the Tuamnagoskaigh in Ballynahown, near Lisdoonvarna, where there is a roofed cleft of some length. A fourth went from Bealboruma fort under the Shannon; through it the angry Brian Boru sent soldiers to waylay and kill his slandered

${ }^{10}$ Ibid., p. 18. The same tale is told of St. Declan and the beautiful perfect round tower of Ardmore, County Waterford.

"Vol. xxii., p. 336; Ordnance Survey Letters (Co. Clare), vol. i., p. I44.

12 Vol. xxii., pp. 57, 456.

${ }^{13}$ The fall of an angel not long before the death of the late Lord Inchiquin greatly strengthened the belief. 
son-in-law the King of Leinster. Others connected Killone with Clare Abbey, and Quin Abbey with St. Finghin's church at the other side of the "Rine."

\section{Miscellanea and Addenda.}

Treasure legends and kunting.-Many forts have been much defaced by persons seeking treasure, though treasure legends are few. Caheiscrebeen, near Lemeneagh castle (the Caherscribnib' of $155 \mathrm{I}),{ }^{14}$ is said to be the richest fort in Ireland, having three rooms full respectively "of gold, deer's tallow, and beor lochlanagh" or Dane's beer (made by a lost recipe from heather and "the finest of all drinks").15 Treasure-hunting is, so far as I bave learned, in nearly every case in consequence of a dream, especially of a dream repeated more than once. No particular ceremony seems to have been used. The dreamer went, usually by night and sometimes alone or sometimes with a few friends, to the spot indicated, and dug until tired and hope of success was lost.' Most of the damage done to stone forts and castles results, in the former from rabbit hunters, and in the latter from people getting material for other buildings. Silver (money) is believed to be buried in the mound of Lismehane castle, and near the curiously scribed rock of Cloch-an-airgid (rock of the silver) near Bohneill castle. I have seen in the field within Dunlicka castle, ${ }^{16}$ near Kilkee, the holes made by a seeker who was told to dig where he saw a rush growing. "The great Clare gold find" in 1845 , near Moghane fort, enriched archaeology rather than folklore. But the finders in some cases believed it to be fairy gold, and the people of Newmarket-on-Fergus tell that those who got it, with one exception, did not profit by it; the one lucky exception did not find his prosperity permanent. The only interesting treasure tale $I$ have found is that of the townland of Skaghvickencrow (MacEnchroe's hawthorn), told by Dr. G. U.

14 In the will of the last recognised King of Thonond, Murrogh, Earl of Thomond.

${ }^{15}$ The Journal of the Royal Society of Antiquaries of Ireland, vol. xxvi., p. 368.

${ }^{16}$ See also vol. $x x i .$, p. 344 . 
MacNamara. ${ }^{17}$ A certain Flann MacDonnchaidh, a very poor man, lived near the bush long ago, and dreamt "again and again" that, if he went to the Bald Bridge, Droichiod maol-na-Luimneaigh (Ball's Bridge in Limerick City), he would find money and make his fortune. He went there and walked up and down until he was worn out. He was on the point of going away when a cobbler asked him what he was about, and he told his story. The cobbler laughed, and told how he himself had dreamed of finding treasure under a bush at a place called Skaghvickencrow, but had wasted no time in looking for it. ${ }^{18}$ MacDonnchaidh returned home, dug, and found a flag with an inscription in an unknown tongue. He left the stone on his hearth, and, as no local scholar could read it, he troubled no more about the matter. Years went by, and one night a wandering schoolmaster asked for hospitality, and of course got it. The "angel unawares" translated the inscription as "one side is more lucky than the other." Next day, when his guest was gone, MacDonnchaidh dug, and found so much money as to make rich men of himself and his descendants. ${ }^{19}$

The only tale of church treasure I have met with is that the silver bells of either Killeany or Kilmoon church lie hidden in the brook between their ruins called from the legend Owenacluggan.

Funerals and graveyards.-Though I have frequently attended funerals of persons of all classes and denominations in many parts of Clare, I have very little to tell of the ceremonies. Sometimes I have seen spades crossed on a grave, and long ago saw three crosses, made of twigs from a hawthorn tree in a graveyard, placed on a coffin. The body is usually carried feet foremost round the graveyard sunwise, and sometimes, but rarely, three times. The horrible habit of digging out all the contents of the grave is usual; the older coffin planks are thrown away, and the human remains

${ }^{17}$ The Journal of the Limerick Field Club, Part 4, p. 42.

${ }^{18} \mathrm{Cf}$. the well-known story of the Swaftham tinker and London Bridge.

19 I heard this tale, perhaps in I870, from John O'Halloran at Edenvale near Ennis, about the Crowes. Certainly that family (MacEnchroe's) has a hawthorn bush in its armorial bearings, and the motto "Skagh M'Enchroe." Dr. MacNamara conjectures that Flann's surname was really MacEnchroe. 
placed on the new coftin. Where burials take place at short. intervals the results are best left untold, but such cases are rare. A consequence of this fearful overcrowding is that no old graveyard is free from coffin planks and plates, bones, and fragmentary or whole skulls." Those who saw Quin "Abbey" before 1879 will remember the enormous heap of skulls, (even then, however, much diminished), heaped round a tree near the graveyard gate. At Tomfinlough the bones and skulls were neatly stacked in a recess, at Kilmacreehy they were heaped on a sort of side altar in the chancel, and in other churches (Coad etc.) I have seen single skulls staring out of holes in the wall.

Places for the burial of strangers and unbaptized children are common, and are usually killeens, old forgotten church sites, sometimes in a fort, sometimes at a well, or unenclosed in a field, ${ }^{23}$. Those at Kilquane, near Ennis ; Fomerla, near Tulla; Kyleeáne, near Barefield (with Doughnambraher stone); and Kilvoydane, near Spansil Hill, have basin stones. Some killeens, such as that between the forts of Mortyclogh, near Corcomroe Abbey, and that at Fortanne, have crept back into favour for adult burial, but several ancient churches at which bones are found have not been so used in traditional memory (e.g. Toomullin, Crumlin, Killonaghan, and Kilbract, round Lisdoonvarna ; Templeline, in Carran; Temple-an-aird, near Carrigaholt ; St. Senan's, on Mutton Island; Temple aed O'Connell, near Ruan; and several churches on Scattery and Iniscaltra). The church of Kilcashen was not remembered to have been a burial place before Eugene O'Curry's grand. father, Melachein O'Curry, in a pestilence about 1760 , charitably collected the deserted unburied corpses "on carts and sledges," and buried them at the ruin on his farm. ${ }^{22}$ Bodies were similarly buried during the Great Famine at the Lisheen, near Lough Fergus. Oughtdarra, near Lisdoonvarna, has the remains of $\cdot a$ church of St. Sinnach MacDara, ${ }^{23}$ where children under seven

\footnotetext{
${ }^{20}$ See also vol. $x x i i$, , p. 56.

"For a list, with notes, see Procedings of the Royal Irish Academy, vol. vi., ser. iii., p. 129 .

20 Kilcashen, Ordnance Survey Letters (Co. Clare), vol. i., p. 369.

${ }^{23} A$ saint famous all round Galway Bay, but not found in the ancienit Calendars. Some suppose him to be a Fox IIero, i.e. Sinnach mac Dara, Fox
} 
years of age are buried; after that age bodies are taken to the parish graveyard at Killilagh. In Shanakill, on the Shannon bank opposite Scattery, it was believed that the dead were moved supernaturally under the river into the Sacred Isle. ${ }^{24}$.

I know of a case in eastern Clare where parents, having lost several of their children, tried to break the deadly record by changing their burial place, but, alas! without success.

I am not aware of any belief in Clare that the spirit of the lastcomer in a graveyard has to watch the place or to bring water to the souls in Purgatory. There was, however, recently a race between two funerals to Rathblamac graveyard, which may imply some such belief. The custom of burying a stone from a church or an ancient tombstone in a new grave, (which has led to the disappearance of several early monuments at Clonmacnoise), prevails at Tomgraney, two ancient tombstones having recently been recovered on digging new graves. As we have already seen, ${ }^{25}$ St. Mochulla's well avenged the encroachment of its landlord on the killeen beside it, but the graveyards of Kildimo, near Kilkee, and St. Catherine's at Kells, near Corofin, are under cultivation. Dr. MacNamara noted a curious allusion to the last-named in O'Daly's fierce satire on "The Tribes of Ireland" in $16 \mathrm{rO}$. The people of Kells are there reproached for "digging the churchyard in the snow." The oldest Irish Law Code, the Seanchus MLr, has a clause against digging in a churchyard or breaking bones there. Kildimo was levelled, and its site included in an orchard by 1816.26 Interference with human remains is deeply and dangerously resented, yet spells are sometimes worked with them..$^{27}$ The stealing of a dead man's hand for a butter charm is said to have taken place near Kilkee, ${ }^{28}$ and the bones of a Franciscan with the brown cloth of his gown still adhering, found during the repairs at Ennis Abbey, were nearly all taken, but probably from most reverential motives.

son of oak tree. There is Knockaunatinnagh (little hill of the foxes) beside his church.

24 Dublin University Magazizze, vol. xviii. (184i), p. 545 .

${ }^{25}$ Vol. xxii., p. 211 .

"W. G. Mason, A Statistical Account etc., vol. ii., p: 434.

"See Burial and Skull Beliefs, vol, xxii., pp. 55-6, 456.

- Vol. xxii., p. 340. 
Charms.29-The charming of rats, which was described by Eugene O'Curry to Dr. J. Henthorne Todd, seems to have been forgotten in the Doonaha district, where, at least, I never heard of it during several visits in the neighbourhood from 1896 . The performance is ancient, being described after A.D. 600 by the famous bard Seanchan Torpeist, a contemporary of King Guaire Aidhne of Gort, who ruled the district adjoining Clare on the north from about A.D. 610. O'Curry's story is that a certain John O'Mulconry joined the Established Church, and was ordained, being eventually advanced to be curate of Kilrush and Kilferagh in the south-west corner of Clare. Now Kilfieragh graveyard was so horribly infested by rats that serious accidents occurred at every burial (I presume from their attacks), and every corpse buried there was entirely devoured by the following morning. The curate, horrified by the scenes he witnessed at a burial, proceeded to charm the rats, as the country folk firmly believed him able to do from his knowledge of old Irish literature. A certain John Foley, of Querin on the Shannon, saw that evening what looked like a bank of low-lying fog crossing a bog between him and Kilfieragh. He fancied it was the fairy host, and ran to one side, when he saw it was a compact body of rats. They went through his cornfield, without stopping, to Querin point, then burrowing into the dry. sand and disappearing. They soon proved as destructive as ever, gnawing the fishermen's nets and boats (probably leather curraghs). The sufferers gathered a great number of neighbours, amongst whom was Owen Mor O'Curry, the writer's father, and proceeded to dig out and kill the vermin. An incredible number were slain, but the survivors seemed innumerable, and in the end, with the courage of despair, 'attacked the slayers, trying to run up their clothes and bite them. Wearied and terrified at the swarms, the peasantry at last gave up the fight and fled. Eugene O'Curry never heard what became of the remnant of the rats.

Thomas O'Keane, a land surveyor, told O'Curry in 1820 that he knew and used an ancient satirical poem to expel rats, and that he had successfully driven out all that infested his house and mill at Bealahaglas, near Dunlicka Castle. The charm was in archaic and enigmatical Irish. Fired by emulation, young O'Curry

2 Addenda to Section xi., vol. xxii., pp. 49-60. 
wrote a satire against the rats, and tried it on an infested house at Kilkee, in the same year, but without success.

About the same time certain men in Limerick City were famous for being able to free ships in that port from rats. Their method was to fix a razor, edge upwards, on the ship, and by their charms to force the rats to cut their throats on it. ${ }^{80}$

Dr. G. U. MacNamara tells me that Denis Curtis near Corofin cures liver complaints, bleeding, and cows that have swallowed raw potatoes. He puts his human patients on their backs on his anvil, and pretends to strike them with a sledge hammer. This is done on three occasions, on two Mondays and a Thursday. The patients then drink forge water. All the family have the gift of healing, but only one exercises. it. The family legend says that St. Patrick's horse lost a shoe near Kilnaboy, and their ancestor shod it gratuitously. The saint therefore endowed the family with the power, and people even return from America to be cured by the smith.

Marriage tabu. - In eastern Clare, a newly-married woman attended Mass on the Sunday next after her marriage, and was severely criticised for doing so. Local opinion held that she and her husband ought not to attend public worship until the second Sunday after the marriage. ${ }^{81}$

$P_{\text {aicas. }}{ }^{82}$-A recent apparition of the puica of Clonlara was described to me in IgI I as a dark, shadowy horse near the bridge over the Blackwater, about two miles to the south-west of the village. My nephew, Dr. Hugh Gerald Westropp, heard of similar

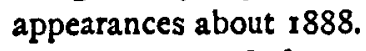

Lucky and unlucky deeds.33_The geasa and buadha, or tabus and lucky acts, relating to the present County Clare are described in the Leabhar na $g$ Ceart (Book of Rights), ${ }^{34}$ in a poem by Cuan na

30 Procedings of the Royal Irish Academy, vol, v., ser. iii., p. 362.

81 I learn from a Petty Sessions case, March, 1911, at Derrygonnelly, that this custom prevails also in Fermanagh, and that friends and relatives do not visit the young couple in the interim, but entertain them on the second Sunday.

${ }^{25}$ Addendum to vol. xxi., p. 481.

"Addendum to section xil., Lucky and Unlucky Deeds, vol. xxii., pp. 203.4.

'Edited by John O'Donovan, 1847, pp. 16-21. 
Leochain, who was slain in 1024 . The King of Cashel (over-king, therefore, of North . Munster) was forbidden to pass a night at Latteragh in northern Tipperary at the beginning of harvest; to encamp for nine consecutive nights at the river Suir; to hold a border meeting at Gowran; and to listen to the groans of women (in a raid) in southern Tipperary. The King of Connacht was not to go in a speckled cloak, - the prose adds "on a piebald horse," - to the heath of Luchaid in Clare. On the other hand, the ruler of Cashel brought good luck by plundering cattle. in Connacht while the cuckoo sings; burning north Leinster; passing over Sliabh Cua,_-"on a Tuesday," says the prose,-to pacify south Munster; crossing Magh Ailbhe with a light grey host; and resting six weeks (of Lent) every year at Cashel. It was most unlucky for him to wait for a feast at Killarney Lake for a full week from.a Monday. At the present day some families still have their.own tabus, lucky and lucky deeds and days, dreams, and omens, which sometimes even run counter to beliefs generally received,-e.g. that the Friday falling on the thirteenth of any montb, or to dream of a wild cat or other wild animal, is lucky.

Witch hare. ${ }^{35}$-Anthony Bruodin (Bruodinus or Prodinus), a Franciscan of Quin Abbey, tells in Corolla Oecodemica Minoritica (Prague, 1664, p. 73) how his uncle (patruzs), Florence of Moynaeo (Moynoe on Lough Derg) went out at the dawn of the first of May with his eldest son Bonaventura, (who died in Spain in 1643), and with their hounds to hunt hares. At last the servants saw one sucking a cow. The hounds chased it, biting it as it escaped, into a cottage, where an old .woman was found torn behind.

... Glasgeivnagh cow: ${ }^{36}$-Vague legends are told of her living at Treanahow, Shallee, and Ballygannon.

Ghosts or fairy men. - Mary (Mescal) Doyle, of Newmarket-onFergus, tells bow she saw two ghostly men in black walking on a road near that village.

Stolen bride. - A legend of a stolen bride at Querin on the Shannon is told in Lady Wilde's Ancient Legends etc. of Ireland (1887), vol. i., p. 49 .

${ }^{26}$ Addendum to vol. $x x i i$. p. 449.

"Addendum to p. \$9 supra. 
In concluding this survey of the traditional. beliefs (other than folk-tales) of County Clare, I am quite prepared to learn that I have failed to secure much that is well known to residents in the county. Even my mistakes and omissions, if they lead the people of Clare to abandon their apathy and to correct and supply the deficiencies of my notes, will have helped on the cause of Irish folklore study, and much that is on the point of being forgotten may be rescued for scientific workers on that most important and fascinating subject. ${ }^{87}$

\section{Thos. J. Westropp.}

"Additional Erratum, vol. xii., p. 54. For Terry Island read Torry Island.

Customs at Death on the Lower Congo.

THE following notes are additions to those already published in Folk-Lore ${ }^{1}$ concerning burial, mourning, and other customs and beliefs connected with death on the Lower Congo.

Burial fees.-The fee for digging a grave is a fowl for each person. If a visitor dies in a town, his people have to pay a pig for the right of burial. If the corpse is taken away, a pig must be paid to the people of every town through which it is carried. This has the effect of reducing the risks of catching infectious diseases, as the bearers, to avoid such heavy fees, will take a body to its native town by wide détours instead of over the usual paths. The body is, however, allowed to pass free if it is that of a man killed by a wild animal, or of a woman dead in childbirth.

Purification.-Those who: dig a grave must; go straight to running water and wash themselves all over. , Those; who, touch a corpse must wash their hands and arms, Those who have dug a grave or touched a corpse cross their outstretched arms until they have washed. : With this sign that they are unclean, no one will want to salute them or to shake hands.

Chiefs' funerals; property put in graves. - When a.chief died in French Congo in November, rgo8, his coffin, made by a native carpenter of my acquaintance, measured, $12 \mathrm{ft}$ by $3 \mathrm{ft} .6 \mathrm{in}$, and

1 Vol., xix., pp. 415-6, 421-3, 428-31 ; vol.' xx., pp. 52, 55-6, 58-61,465, 475 . 